\title{
УДК 371.24
}

Наталя СТОВПНИК,

orcid.org/0000-0001-7939-5516

старший викладач кафедри філологічних та природничих дисциплін ЦМО ІМСО Наџіонального авіаційного університету (Київ, Україна) martamartik@meta.ua Тетяна ФІЛАТОВА, orcid.org/0000-0002-0993-223X старший викладач кафедри філологічних та природничих дисииплін ЦМО ІМСО Наџіонального авіаційного університету (Київ, Украӥна)filatova.tatyana.иа@gmail.com

Оксана АНДРІЯШИК, orcid.org/0000-0001-6522-6885 кандидат філологічних наук, старший викладач кафедри філологічних та природничих дисииплін ЦМО ІМСО Начиіонального авіаційного університету (Київ, Україна)aоr5@ukr.net

\section{МОДЕЛЬ НАВЧАЛЬНОГО ЗАНЯТТЯ 3 ЕЛЕМЕНТАМИ ІНТЕРАКТИВНИХ ТЕХНОЛОГІЙ}

Перед системою вищої освіти в иілому та викладачами зокрема постає потреба якісних змін у підготовиі спеціалістів та виникає необхідність упроваджувати в навчальний процес такі форми, прийоми, методи $і$ засоби навчання, які максимально інтенсифікують навчальний процес та сформують активну, творчу, свідому особистість. Тому метою статті є розгляд потирених нині інтерактивних методів навчання як форм організації пізнавальної діяльності у вищій школі. Особливу увагу приділено прочесові активізації навчання. Він розглядається як результат стимулювання 
активності студентів, щзо реалізується иляхом застосування інноваційних методів, форм та засобів навчання, які забезпечують активну й самостійну теоретичну $і$ практичну навчально-пізнавальну діяльність. Здійснено спробу розробити модель навчального заняття 3 елементами інтерактивних технологій (на прикладі використання кейс-методу $i$ «мозкового штурму»). Проаналізовано підходи до сутності навчально-пізнавальної діяльності, з'ясовано особливості інтерактивних методів навчання та їх види.

Методи активізації навчально-пізнавальної діяльності розглядаються як сукупність прийомів і способів психолого-педагогічного впливу на студентів, щуо насамперед спрямовані на розвиток творчого самостійного мислення, формування вмінь нестандартного розв'язання проблем $i$ вдосконалення навичок професійного спілкування. Узагальнюючи відомі авторські підходи до означеної проблеми, з'ясовано, щуо головною метою активізації є покращення якості навчально-виховного прочеесу за рахунок самостійності та активності студентів вищчих навчальних закладів. Визначено, щ⿻о особливість інтерактивного навчання полягає в тому, щуо навчальний процес здійснюється за умови постійної, активної взаємодії усіх його членів. Аналізуючи свої дї, учасники навчального прочесу змінюють свою модель поведінки, більш усвідомлено засвоюють знання та вміння, тому $е$ сенс говорити про інтерактивні методи не тільки як засіб покращуення навчання, але й як спосіб посилення виховних впливів.

Ключові слова: викладач, метод, інтерактив, пізнавальна діяльність, вищза школа.

Oksana ANDRIYASHIK, orcid.org/0000-0001-6522-6885

Candidate of Philological Sciences,

Senior Lecturer in Philology and the natural disciplines of CMO IMSO

National Aviation University (Kyiv,Ukraine)aor5@ukr.net 
Natalia STOVPNIK,

orcid.org/0000-0001-7939-5516

Senior Lecturer in Philology and the natural disciplines of CMO IMSO

National Aviation University (Kiev,Ukraine)martamartik@meta.ua

Tatiana FILATOVA, orcid.org/0000-0002-0993-223X

Senior Lecturer in Philology and the natural disciplines of CMO IMSO

National Aviation University (Kiev, Ukraine) filatova.tatyana.ua@gmail.com

\section{MODEL OF EDUCATIONAL TRAINING WITH ELEMENTS OF INTERACTIVE TECHNOLOGIES}

The higher education system as a whole and teachers in particular are faced with the need for qualitative changes in the training of specialists and there is a need to introduce into the educational process such forms, techniques, methods and means of teaching that maximize the educational process and form an active, creative, conscious personality. Therefore, the purpose of the article is to consider the current interactive teaching methods as a form of organization of cognitive activity in higher education. Particular attention was paid to the process of learning activation. It is considered as a result of stimulating the activity of students, which is realized by the way of the application of innovation methods, the form and the means of learning, which provide active and self-active learning. An attempt has been made to develop a model of training with elements of interactive technologies (for example, the use of the case-method and «brainstorming»). Approaches to the essence of educational and cognitive activity are analyzed, the features of interactive teaching methods and their types are found out.

The mentioned methods are considered as means of influence of students, first of all aimed at the development of creative thinking, the formation of creative skills and 
the ability to solve non-standard solutions to problems. Taking into account the known approaches of the author to the problem, it is found out that the main goal of activation is to increase the quality of the scientific and educational process of the student. It is determined that the feature of interactive learning is that the educational process is carried out under the condition of constant, active interaction of all its members. By analyzing their actions, participants in the learning process change their behavior, more consciously acquire knowledge and skills, so it makes sense to speak of interactive methods not only as a means of improving learning, but also as a means of enhancing educational influences.

Key words: teacher, method, interactive, cognitive activity, high school.

Постановка проблеми. В умовах соціально-економічних змін у суспільстві та зростання конкуренції на ринку праці застарілі методики стають досить вузькими для виконання поставлених завдань. Однак, від того, яких фахівців ми готуємо сьогодні, залежить інтелектуальний та духовний потенціал нації в майбутньому. Зважаючи на це, постає необхідність пошуку нових методів навчання студентів у вищій школі 3 метою вдосконалення їхніх навичок, формування якості дослідника, активізації пізнавальної діяльності.

Аналіз досліджень. Досвід, описаний відомими педагогами, а також багатолітня практика підготовки спеціалістів, переконує, що навчальна діяльність студентів, iï структура, методика іiі організації в цілісному дидактичному процесі належать до центральних проблем дидактики та педагогіки у вищих навчальних закладах освіти. Аналізуючи проблему активізації пізнавальної діяльності на основі педагогічної літератури та наукових джерел, бачимо, що вона розглянута видатними вченими з позицій різних концепцій. Виділимо основні напрями досліджень:

- пошукам шляхів покращення навчального процесу та підвищення пізнавальної активності студентів присвятили свої дослідження відомі вчені-педагоги: В. Лозова, Г. Щукіна, Т. Шамова, І. Зязюн, А. Лузан, О. Пєхота, А. Кіктенко, О. Любарська, В. Мороз; 
- дослідженням педагогічної системи та педагогічного процесу вищого навчального закладу присвячені праці науковців Я. Каменського, В. Сухомлинського, С. Гончаренка, Ю. Бабанського;

- загальні проблеми активізації пізнавальної діяльності в умовах загальноосвітньої школи висвітлені у працях П. Атаманчука, В. Лозової, Г. Щукіна.

Мета статті. Проблема використання в дидактичному процесі методів активізації навчально-пізнавальної діяльності студентів залишається недостатньо розкритою на рівні вищих навчальних закладів. Відтак, метою статті постає потреба дослідження активізації пізнавальної діяльності студентів, з'ясування особливостей інтерактивних методів навчання та їх видів.

Виклад основного матеріалу. Перед викладачами вищих навчальних закладів дедалі частіше постають питання: як поєднати обсяг матеріалу дисциплін із якісним навчанням, якого спеціаліста потрібно готувати сьогодні. Безумовно, спеціаліста, який відповідатиме низці критеріїв: насамперед буде вміти оновлювати, трансформувати свої знання залежно від вимог та досягнень часу; знаходити необхідну інформацію, використовуючи сучасні інформаційні технології; постійно займатися самоосвітою. Педагоги перебувають у постійних пошуках форм і методів навчання, які б давали найвищий коефіцієнт засвоєння студентами навчального матеріалу. До основних чинників активізації навчального процесу належать індивідуальний та диференційований підходи, розвиток творчої особистості студента за рахунок використання в навчальному процесі мультимедійних технологій та комп’ютерної техніки, прикладних програм, засобів моделювання, наочних елементів, постановки проблемних питань, відтворення виробничих ситуацій та презентації висновків, демонстраційного експерименту, постійної індивідуальної роботи 3 новою літературою, дискусій у ході занять, а також упровадження інтерактивних елементів дослідницької діяльності в навчальний процес.

В основі пізнавального процесу лежить діалектична формула пізнання активність як ставлення й взаємодія людини 3 навколишнім світом, який 
пізнається. Активізація навчання - це «характеристика особливостей пізнавальної діяльності особистості, що полягає в усвідомленому використанні нею інтенсивних методів, засобів, форм оволодіння знаннями, вироблення вмінь і навичок». Таке визначення міститься у педагогічному дослідженні А. Рацул (Рацул, Довга, 2015: 37). Діяльність - спосіб існування людини в світі, здатність ii вносити у дійсність зміни. Завдання освіти - перетворити навчання в задоволення, у процес, що збагачує особистість. Пізнавальна активність - це своєрідний інтелектуально-емоційний відгук на процес навчання, вміння самостійно думати, орієнтуватися в новій ситуації, знаходити свій підхід до вирішення завдань, бажання не тільки оволодіти знаннями, а й знати шляхи їх здобування, креативний та дещо критичний підхід до висновків інших i, як наслідок, незалежність думкок. Таким чином, навчальний процес - це складна педагогічна система, кожний компонент якої спрямований на формування високопрофесійної особистості та розвиток її творчих здібностей.

Активні методи навчання це, насамперед, - методи, які спонукають студентів до активної розумової та практичної діяльності в процесі вивчення навчального матеріалу. Активне навчання передбачає використання такої системи методів, яка спрямована на подання викладачем готових знань, їх засвоєння та відтворення, а також на самостійну роботу. Особливістю активних методів є те, що в їх основі закладена мотивація до практичної і розумової діяльності. Узагальнюючи відомі авторські підходи до означеної проблеми, ми можемо дійти висновку, що головною метою активізації є покращення якості навчально-виховного процесу за рахунок самостійності та активності студентів вищих навчальних закладів.

Активізацію діяльності студентів необхідно здійснювати на початковому етапі навчання за допомогою активних методів навчання. Спробуємо проаналізувати деякі із зазначених методів. Серед них, зокрема, принцип т. зв. «мозкового штурму» (атаки) та його різновидів. 
Мета цього інтерактивного методу полягає в активізації інтелектуальної діяльності студентів, яка спрямовується на висування ідей, вирішення конкретнго завдання, на пропозицію шляхів розв'язання певної проблеми.

Інтерактивний метод «мозкового штурму» та його варіанти об'єднує загальна мета та певна кількість правил проведення. Ціллю методу можна назвати звільнення студентів від інерції мислення, подолання стереотипів. Головними правилами проведення «мозкового штурму» можна вважати такі:

1. відсутність критики запропонованих учасниками ідей;

2. заохочення до фантазування, жартів, дотепних реплік;

3. фіксація учасниками всіх без винятку ідей;

4. повна рівноправність усіх учасників у висуванні ідей;

5. чіткі часові обмеження (від 5 до 15 хвилин).

Найоптимальнішою кількістю учасників «мозкового штурму» можна визначити 5-7 осіб. Робота починається із постановки проблеми, яку необхідно вирішити. Викладач повинен бути впевнений, що студенти розуміють, що від них очікують, що вони мають можливість фіксувати ідеї, що їхнє розміщення в аудиторії дозволяє спілкуватися без перешкод: тобто найзручнішим $\epsilon$ розташування довкола столу, коли учасники бачать обличчя один одного і в них $\epsilon$ місце, щоб робити записи. Тому проведення «мозкового штурму» в стандартній аудиторії - амфітеатрі є дуже незручним, оскільки не дозволяє всім учасникам групи вільно спілкуватися, добре чути один одного, бачити записи. Після закінчення часу, відведеного на роботу, студенти озвучують ідеї, які були висунуті при колективному обговоренні. Разом із викладачем починається розгляд цих ідей, аналізується їхня доцільність для вирішення поставленої проблеми. Результатом є вибір найбільш оригінальної, нестандартної ідеї.

Варіантом «мозкового штурму» може бути пряма колективна «мозкова атака» із кількістю учасників до 15 осіб. Умови такого штурму залишаються незмінними, а час проведення може бути збільшений до 45-50 хвилин. Масова «мозкова атака», з кількістю учасників до 60 осіб може проводитися із потоком студентів. Учасники діляться на групи по 5-6 осіб. Після цього кожна група 
проводить пряму «мозкову атаку» протягом 15 хв. Представники кожної групи повідомляють ідеї і під керівництвом викладача проводиться їхня оцінка та вибір найоригінальнішої. Цей вибір можна провести шляхом голосування. Для цього ідеї всіх груп (за винятком тих, що повторюють одна одну), фіксуються (на дошці, виводиться на екран за допомогою комп'ютера, іншим способом) i студентам пропонується оцінити їх.

Однак існує більш складний варіант «мозкового штурму», скажімо, діалог із деструктивною відносною оцінкою. У його основі лежить протиставлення: ідея-контрідея. Тобто висування ідей проводиться за тими самими правилами, що й у простому «мозковому штурмі», але потім здійснюється їх аналіз та критика на предмет реальності втілення, ефективності для досягнення результатів у вирішенні поставленої проблеми. Тому організація та проведення такої інтерактивної роботи значно складніші.

Організація «мозкового штурму» із деструктивною відносною оцінкою передбачає таку послідовність дій викладача і студентів:

1.Формування малих груп.

2. Визначення похідної задачі

3. Генерування ідей за принципом «мозкової атаки».

4. Систематизація та класифікація ідей.

5. Деструктурування ідей, тобто оцінка ідей на можливість втілення у життя.

6. Оцінка критичних зауважень, які були висловлені на попередньому етапі.

Роль викладача при організації аудиторної роботи - спостереження за поведінкою студентів (не можна допускати вільного пересування по аудиторії, якщо це не викликано необхідністю, голосного обговорення, телефонних розмов, байдужого ставлення до обговорення, самоусунення студентів від роботи), стеження за дотриманням правил (порушення рівних прав учасників групи на висловлювання, критичні зауваження на етапі висунення ідей, захоплення одноосібного лідерства), за часом, відведеним на кожен етап роботи 
(необхідно повідомляти про закінчення часу одного етапу та про необхідність переходу до іншого, наполягати на такому переході), створення робочої атмосфери (відповідна підготовка приміщення, усунення будь-яких перешкод для повноцінної роботи). Треба пам'ятати, що викладач не є консультантом, тому не має права втручатися в обговорення, вказувати на помилки або хибність ідеї. Він може висловити свої зауваження наприкінці заняття. Найчастішими помилками викладача $\epsilon$ неправильний розрахунок часу, відведеного на кожен етап роботи, висування занадто складної, об'ємної похідної задачі, повноцінне обговорення якої не може бути здійснене протягом двох навчальних годин; втручання у роботу груп. Крім того, треба пам'ятати, що студенти не є ще фахівцями, що вони тільки навчаються, i тому не завжди повністю, багатоваріантно розробляють ідеї, вирішують проблему. Нищівна критика з боку викладача може викликати в студентів невпевненість у своїх силах, зруйнувати інтерес до інтерактивної форми роботи. Педагог зобов'язаний створювати при обговоренні «ситуацію успіху», поряд зі зваженими критичними зауваженнями підкреслювати творчі успіхи, заохочувати до подальшої роботи.

Наступний інтерактивний метод, який заслуговує на увагу - це групове вирішення конкретних ситуацій (ситуаційна методика навчання, або кейс-метод). Він може мати як індивідуальний, так i груповий варіанти. Ситуація (кейс) може бути запропонована для аналізу студенту у формі завдання для самостійної індивідуальної роботи, а може бути використана при організації групової аудиторної роботи.

В основі цієї методики лежить розгляд, аналіз, пошук рішення у так званій ситуаційній вправі (кейсі). $€$ достатньо літератури, у якій детально розглядаються питання підготовки кейсів (Павлович, 2012: 4), організації роботи з ними, де пропонуються для навчального процесу вже готові ситуації. Тому ми згадаємо тільки найголовніші моменти. Проблема, що розглядається в ситуаційній справі, вимагає збирання відповідних даних, встановлення точного «діагнозу» i/або формування прогнозу та вибору «найкращого рішення» 3 
огляду на прийняті критерії оцінки. У правовій освіті це опис реальної юридичної справи, представленої відповідними документами. Без сумніву, ситуаційні вправи можуть бути створені для інженерів, архітекторів, медиків, тобто для студентів, які вивчають різні фахові дисципліни і опановують різні професії. Однак, усі ці ситуаційні вправи мають спільну структуру.

Ситуаційна вправа - це комплексний опис ситуації, в якому можна виділити низку взаємопов'язаних структур або рівнів: пізнавальних, понятійних, навчальних, суспільних, аналітичних, евристичних, мотиваційних тощо. Межі поміж цими компонентами не є чіткими і однозначними, навпаки, ці структури взаємно проникають і накладаються одна на одну.

Пізнавальна складова ситуаційної вправи - це, передусім, фактографічні елементи, які розширюють, доповнюють знання студента певними конкретними прикладами, взятими 3 життя. 3 ними пов'язані понятійні структури ситуаційна вправа змушує оперувати точною, професійною мовою, в якій вживання визначень і понять є однозначним і зрозумілим для студента та його партнерів, які беруть участь в обговоренні та презентації рішень стосовно ситуації, що аналізується. Дидактична складова структури ситуаційної вправи головним чином визначається сутністю й атрибутами аналізу ситуації як активного методу навчання. Суспільна структура ситуаційної вправи відображає можливість групового обміну думками й зіставлення різних точок зору, яке відбувається у формі колективної дискусії. В аналітичній площині ситуаційна вправа змушує до «індивідуального» способу мислення i поглибленого аналізу-розкладання складної ситуації на «початкові елементи» (прості ситуації), які можна легше й конкретніше оцінити. Це дозволяє визначити варіанти можливих рішень і вибрати з них те, яке з певного погляду $є$ найкращим (евристичний компонент). Мотиваційна складова структури ситуаційної вправи поєднується зі створенням цікавої дидактичної ситуації, яка стимулює і залучає студента до пошуку шляхів розв'язання проблеми кейсу. Таким чином, використання ситуаційної вправи у груповій роботі базується на внутрішньо-груповому діалозі, або на організації «мозкового штурму». 
Результати роботи різних груп можуть бути порівняні між собою, може бути обране найкраще рішення.

Висновки. Таким чином, ми розглянули лиш декілька прикладів використання інтерактивних методів у вищій школі. У результаті проведеного аналізу з'ясовано, що активізацію діяльності студентів науковці пропонують здійснювати на початковому етапі навчання за допомогою сучасних педагогічних технологій i активних методів навчання. Особливість інтерактивного навчання полягає у тому, що навчальний процес здійснюється за умови постійної, активної взаємодії усіх його членів. Аналізуючи свої дії, учасники навчального процесу змінюють свою модель поведінки, більш усвідомлено засвоюють знання та вміння, тому $\epsilon$ сенс говорити про інтерактивні методи не тільки як засіб покращення навчання, але й як засіб посилення виховних впливів.

\section{СПИСОК ВИКОРИСТАНИХ ДЖЕРЕЛ}

1. Амеліна С. М. Тренінги з розвитку умінь та навичок діалогічного спілкування: посібник / С. М. Амеліна. Д.: Пороги, 2005. 73 с.

2. Використання інтерактивних технологій навчання в професійній підготовці майбутніх учителів. К.: Наук. світ, 2003. 138 с.

3. Інноваційні пошуки в сучасній освіті / За ред. Л. І. Даниленко, В. Ф. Паламарчук. К.: Логос, 2004. 220 с.

4. Інтерактивні технології навчання / Авт. колектив: О. І. Прометун, Л. В. Пироженко, Г. І. Коберник та інш. К.: Наук. світ, 2004. 85 с.

5. Павлович А. В. Використання інтерактивних методів навчання у викладанні іноземної мови професійного спрямування у вищій школі / А. В. Павлович // V Міжнародна науково-практична конференція «Сучасні методи викладання іноземної мови професійного спрямування у вищій школі». 2012. С. 4. [Електронний ресурс]. Режим доступу: http://confesp.fl.kpi.ua/sites/default/files/tezi.pdf.

6. Рацул А. Б., Довга Т. Я., Рацул А. В. Педагогіка: інформативний виклад: Навчальний посібник. - 2-ге вид., перероб. і доп. К.: КНТ, 2015. 320 с. 


\section{REFERENCES}

1. Amelina S. M. Treninhy $\mathrm{z}$ rozvytku umin ta navychok dialohichnoho spilkuvannia: posibnyk / S. M. Amelina. [Amelina S. M. Trainings for the development of dialogues: a guide / SM Amelina.], 2005. 73 p. [in Ukraine].

2. Vykorystannia interaktyvnykh tekhnolohii navchannia $\mathrm{v}$ profesiinii pidhotovtsi maibutnikh uchyteliv. [Use of interactive teaching technologies in the training of future teachers]. K.: Scientific World, 2003. 138 p. [in Ukraine].

3. Innovatsiini poshuky $\mathrm{v}$ suchasnii osviti / $\mathrm{Za}$ red. L.I. Danylenko, V. F. Palamarchuk. [Innovative searches in modern education / Ed. L. I. Danilenko, V. F. Palamarchuk]. K.: Logos, 2004. 220 p. [in Ukraine].

4. Interaktyvni tekhnolohii navchannia / Avt. kolektyv: O. I. Prometun, L. V. Pyrozhenko, H. I. Kobernyk ta insh. [Interactive Learning Technologies / Ed. collective: O. I. Prometun, L. V. Pyrozhenko, G. I. Kobernyk and others]. K.: Science. World, 2004. 85 p. [in Ukraine].

5. Pavlovych A. V. Vykorystannia interaktyvnykh metodiv navchannia u vykladanni inozemnoi movy profesiinoho spriamuvannia u vyshchii shkoli / A. V. Pavlovych // V Mizhnarodna naukovo-praktychna konferentsiia «Suchasni metody vykladannia inozemnoi movy profesiinoho spriamuvannia u vyshchii shkoli». [Pavlovich A. V. The use of interactive teaching methods in teaching a foreign language of vocational guidance in higher education / A. V. Pavlovich // V International scientific-practical conference «Modern methods of teaching a foreign language of vocational guidance in higher education». [Electronic resource]. Access mode: http://confesp.fl.kpi.ua/sites/default/files/tezi.pdf.]. [in Ukraine].

6. Ratsul A. B., Dovha T. Y., Ratsul A. V. Pedahohika: informatyvnyi vyklad: Navchalnyi posibnyk. - 2-he vyd., pererob. i dop. [Ratsul A. B, Dovga T. Y., Ratsul A. V. Pedagogics: informative presentation: Textbook. - 2nd edition, remaking. and ext.]. KT: CST, 2015. 320 p. [in Ukraine]. 